\title{
Complexity and Adaptive System of Television Broadcasting: The Reflection of Autopoetic Mechanism of Indonesian Television Broadcasting System
}

\author{
Hermin Indah Wahyuni•
}

\begin{abstract}
This article aims to describe a model of a robust adaptive system which suits the context of situation in Indonesian as an archipelago, as well as developing and democratic values-based country. It mainly focuses on how the autopoetic mechanism in Indonesian television broadcasting system is. Autopoetic mechanism is self-reference orientation. The process in which the system orient to reduce their problem by building the internal structure to cope with it. The research process was done in 2014 until 2016. Methods applied in this research is qualitative research. Several methods that were employed are observation, in-depth interview, and focus group discussion. It would be measured and analysed with three aspects: communication, temporal and differentiation aspect. The findings suggest that building a robust system means establishing a "strong and adaptive" broadcasting system in Indonesia that strengthens each sub-system in the Indonesian broadcasting system in order to capture what the public demands. In this level it takes a comprehensive view of the decision-makers to design a broadcasting system that continues to answer the demanding environment through its communication function, growing temporal through continuous evolution and develop functions through a process of differentiation. If these three functions can work continuously, Indonesian broadcasting system will be stronger and more adaptive with their complex external environment. The main argument of this paper is Indonesian Broadcasting System faces a very complex environment television, however their adaptive and autopoetic mechanism is still weak to cope with the challenges.
\end{abstract}

\section{Keywords:}

television broadcasting system; complexity; adaptive; autopoetic-mechanism; differentiation.

\begin{abstract}
Abstrak
Sistem penyiaran televisi Indonesia saat ini berada dalam situasi krisis, sangat lemah dan tidak adaptif dengan situasi lingkungan yang melingkupinya. Tujuan penulisan artikel ini adalah untuk mendeskripsikan mengenai pengembangan sistem yang kuat dan adaptif disesuaikan dengan konteks situasi Indonesia sebagai negara kepulauan, sedang berkembang, dan berbasis pada nilai-nilai demokratis. Fokus artikel adalah menggambarkan mekanisme autopoetic terefleksikan dalam sistem penyiaran Indonesia. Mekanisme autopoetic adalah mekanisme yang berorientasi pada kebutuhan sistem sendiri. Sistem akan berorientasi untuk mereduksi problem mereka dengan membangun struktur internal untuk mengatasi problem di luar dirinya. Riset dilaksanakan mulai tahun 2014 hingga 2016. Metode yang diterapkan adalah riset dengan paradigma kualitatif. Metode pengumpulan data yang diterapkan adalah observasi, wawancara mendalam secara intensif, diskusi dengan kelompok terfokus, dan analisis isi kebijakan yang relevan. Sistem penyiaran akan diukur dan dianalisis dengan menggunakan tiga aspek refleksi cybernetic yaitu aspek komunikasi, pertumbuhan dari waktu ke waktu (evolusi) dan kemampuan diferensiasi internal. Hasil penelitian menunjukkan bahwa kebijakan penyiaran Indonesia yang tangguh bermakna ketika sistem dan sub elemen sistemnya "kuat dan adaptif" menangkap apa yang dibutuhkan publik. Argumen utama dalam artikel
\end{abstract}

\footnotetext{
- Department of Communication Science, Faculty of Social and Political Sciences, Universitas Gadjah Mada. Email: herminkilo12@gmail.com.
} 
ini adalah sistem penyiaran Indonesia menghadapi lingkungan yang sangat kompleks. Namun sayang sekali bahwa kemampuan adaptif dan mekanisme autopoetiknya masih sangat lemah untuk menghadapi tantangan lingkungan tersebut.

\section{Kata Kunci:}

sistem penyiaran televisi; kompleksitas; adaptif; mekanisme autopoetic; diferensiasi.

\section{Introduction}

Television broadcasting is the most dominant mass media in the media landscape in Indonesia. According to the latest data, the number of households who have TV in Indonesia has reached 86.7 percent, equivalent to 56.4 million households (Kominfo, 2015). It means television is watched by almost the entire population of Indonesia. Nevertheless, this massive audience reach is not supported by the broadcasting-product quality that is very far from ideal. People hope that broadcasting institution should set up a forum to provide healthy information. Instead, Indonesian broadcasting system is often regarded as a trigger for major social and political issues. Indonesian television broadcasts often become the subject of discussion in political-economic studies with analyses that intend to uncover the relations between economics and politics (Mosco, 2010) which affect the quality of Indonesian broadcasting system. Intensive studies on the Indonesian broadcasting have been conducted by some scholars (e.g., Sudibyo, 2004; Wahyuni, 2006; Hollander et al., 2009; Hendriyani et al., 2011; Nugroho et al., 2012; Sudibyo and Patria, 2013).

The portrait of private television broadcast programs in Indonesia shows how the market logic dominates the products generated by television programs. All programs have been driven by market, lead by rating. They produce and reproduce program that favour by the people, although its very far from good quality standard. Unfortunately this market logic does not only characterize non-informative programs (entertainment), but also has dictated the informative programs (Thussu, 2007).
Concerns about public interest in a broad sense in Indonesia cannot be avoided when Indonesia sky is marred by programs which simply erode 'citizenship'. Citizenship in this context related with position in which audience is not only viewed as consumer but also as part of Indonesian community. In this position they have a rights to receive useful information that they can use it to take decison for living in social context. Thus, the impression that Indonesian television presents 'waste-land' is hard to neglect.

Complaints and negative comments regarding the quality of Indonesian television cannot be separated from the broadcasting policy which constitutes the core of the national broadcasting regulation system in Indonesia. This article aims to analyze Indonesian broadcasting system by using a systemic perspective; to illustrate the gap between the existing and the ideal conditions; and to offer the optimum broadcasting system to achieve those expectations. The main argument of this paper is Indonesian Broadcasting System faces a very complex environment, however their adaptive and autopoetic mechanism is still weak to cope with the challenges.

\section{Theoritical Framework}

This study applies theories on media policy as a basis for its analysis. These theories basically illustrates two important dimensions, namely the normative dimension of the media policy and the decision-making process itself. Based on the normative aspect, the media policy implemented by a country cannot be separated from its historical context and sociopolitical norms which are applied amidst the 
community. According to Gerhard Vowe (1999), media policy is a tug of war among at least three main norms, namely security, freedom and equality. This article will use these three norms to explore Indonesian media policy. The second dimension of a media policy is an emphasis on the media policy-making process itself. This dimension attempts to describe the dynamic processes in media policy formulation. The concepts of 'rational choice' and 'public choice' are two important concepts which can describe the tug of war between political actors and actors from the media themselves (Fleck, 1983; Creech, 2007; Tassel, 2011; Papathanassopoulos, 2010).

To understand the important points of the Indonesian broadcasting media policy, three important aspects of the 'regulatory regime' concept, namely ideas, institutions and policies of a policy were selected as the main points of the analysis. The problems and challenges of the broadcasting policy in an attempt to realize democratic broadcasting processes in Indonesia will be analyzed based on several critical perspectives on media and democracy (May, 2009). Some of those which are relevant and affecting the analysis of this study are the writings of James Curran on Democracy and Power (2002), Television and the crisis of Democracy by Douglas Kellner (1990), as well as the writings of Philip Kitley (2003) on the dynamics of television, regulations and the strengths of civil society movements to understand the typical context of the television system in Asia. TV system in Asia coloured by spesific situation related with the dynamic of socio-cultural and economy-politic that will influence the character of broadcasting system in this region.

\section{System Perspective}

System theories stemmed from two key concepts, namely the cybernetics concept and the autopoetic concept. Cybernetics is a study of system regulations and control. It is the study of feedback. It is closely related to the way a system orientates towards an effect and the way it estimates a specific goal (West and Turner, 2010). Using a more detailed perspective, Griffin (2012) described cybernetics as a study of how a system determines its effect and makes necessary adjustments. The fundamental output-feedback-adjustment processes are the core of cybernetics (Griffin, 2012).

The cybernetics capability referred here is related to the ability of a system to retrieve information from its environment which is relevant to the system's specific development. A broadcasting system is assumed to begin with determining problems and a variety of uncertain conditions, determining and selecting any existing information, processing using the system and providing feedback on the environment as the output of the system operation. The types and specifications of the feedback cycle are described in Walter Buckley's "Morphogenic Process" model of social system (Johnson, 2008). In this model, there are several concepts such as: Morphogenesis, may be considered as deviation-amplifying feedback cycle: a deviation-amplifying feedback cycle is one in which some deviations are reinforced and thereby provide the foundation for additional foundations in the same directions (Johnson, 2008). Morphostasis, refers to mechanism that tend to preserve or maintain a system's given for organization or state (Johnson, 2008). Entropy refers to the process of decay or decline of a social system or simplification of its structure (Johnson, 2008). Negentropy is a system which overcomes the effects of entropy by importing sufficient energy and resources to prevent decay and maintain their basic patterns of organization if they are to survive (Johnson, 2008).

The second most important concept namely self-autopoetic. It is the key concept from social system theory developed by Niklas Luhmann, a sociologist from Germany. Luhmann (1995) gave special definition in the 
concept of self-autopoetic. Etymologically, the word autopoietic comes from two Greek words, namely auto meaning itself and poiein which means creating. Thus, it can be interpreted that autopoietic is the process of self-creation performed by a system. Autopoietic, initially was a term introduced by Humberto Maturana and Francisco Varela to define biological systems or living creatures such as cell system, nervous system, and immune system and so on. (Luhmann,1995)

Luhmann made a breakthrough by using autopoetic concept to explain the social systems (community). To be precise, Luhmann explained that autopoietic concept is the social systems. In general, autopoietic is defined as the process of continous differentiation carried out by different systems or environments (Luhmann,1995). Autopoietic system creates its own elements (selfcreation) through self-reference mechanism and differentiation (self-differentiation) between itself and the environment. As a future perspective in this study later on, Indonesian broadcasting system will be viewed from its ability to produce and reproduce the differentiation in response to its environment.

Luhmann system theory boils down to three basic components that later becomes a core part of his last book, Die Gesellschaft der Gesellschaft, namely: communication, evolution and differentiation (Lee, 2000). These three components are linked to the social dimension (communication), temporal (evolution), and functional (differentiation). Functional dimension produces the difference between the system and the environment. Temporal dimension is associated with past and future, while social dimension produces difference between ego and alter (Mattheis, 2012). Everything started from communication.

For Luhmann, communication is a sui generis situation born from the synthesis of three different selection process, namely selection of information, selection of utterance, and selective understanding (Mattheis, 2012).
Evolution simply is the process of trial-anderror. Evolution then explained further through the implementation of three functions in a set of processes namely variation, selection and stabilization (Ritzer \& Goodman, 2004). Meanwhile, related to functional dimension, the working of differentiation is the main way of working in the theory of social systems by Luhmann. Differentiation is a replication process that takes place within a system, referring on the difference between a system with its environment. Differentiation process increases the complexity of the system and will generate a lot of variation in the system to respond to variations in the environment. Thus, there arises a paradoxical statement that only complexity can reduce complexity.

If the concepts are derived on the Indonesian broadcasting system, then the capacity of Indonesian broadcasting system to reflect communication, temporal, and social functions will appear. The communication element reflects the system competence in the information selection from the environment. Temporal element reflects the evolution process of Indonesian broadcasting system and finally functional system reflects the competence of the system in adapting to its environment through the differentiation function.

\section{Methods}

Method in this research is qualitative research, which emphasizes on inductive exploration in Indonesian broadcasting system. Qualitative research is a type of research that highlights the principle of understandingverstehen the phenomenon (Wimmer and Dominick, 2011). Qualitative research has characters: known as interpretation/responsive, usually inductive, identifies concept, outcome illuminates the situation, and truth search as context bound (socially constructed) (Flick, 2005).

Two units of observation were set up as guidance for research execution. First 
unit explores the sub-systems in Indonesian broadcasting system and their present condition. The sub system in Indonesian broadcasting system, namely Public broadcasting Institution, Private-commercial broadcasting, Pay TV, and community TV. The second unit is analysing the possibilities and the most likely solution for the construction of a strong and adaptive broadcasting system to meet the existing challenges.

The first focus of this research is to explore the various sub-elements in the Indonesian broadcasting system. Each subsystem within Indonesian broadcasting system would be described using systemic reflection. Each elements of the broadcasting system is compared with the ideal norms that must be optimized. In this first focus, the analysis has aim to determine the critical points that cause weaknesses in Indonesian television broadcasting system. The determination of the critical points obtained by comparing the facts exist in the field with the environmental demands around the external broadcasting system which should be answered. The second focus of this research is to analyze the possibilities and the potentialy adaptive solution for the construction of strong broadcasting system to meet the challenges.

The research was conducted from March 2014 until the middle of 2016. Data collection in 2014 was focused on mapping the problems in the public broadcasting system and the community broadcasting. Meanwhile, throughout 2015 the researchers focused on the exploration of the private commercial broadcasting system and Pay-TV. In 2016 the researchers explored the latest condition in Indonesian broadcasting TV about the preparation to face digitalization.

To get the required data, some methods of collecting data have been done, namely data collection through observation / field research, Focus Group Discussion (FGD), in depthinterview and a study document (content analysis policy). The style of triangulation method was implemented to get comprehensive data about the object. Researchers held observation about the latest situation in public broadcasting TV and private commercial broadcasting TV. The field research had been executed in public broadcasting system TVRI on local level (Yogyakarta, Bandung) and national level in Jakarta. While the field research was done on two private tv stations in Jakarta; Indosiar and TV One.

To collect more data, in-depth interviews had been conducted with key persons in public broadcasting TVRI, namely the supervisory board and directors of TVRI. In private commercial broadcasting in-depth interviews were held with the directors of news and entertainment programs. In order to get comprehensive view focus group discussion that invited several key persons in private commercial broadcasting from the internal institutions and also the broadcasting expert, was conducted. The aim of using several methods here is an effort catch comprehensive data and perspective in this issue.

\section{The Indonesian Broadcasting System: Complexity of Sub-System and the Autopoetic Reflection}

Broadcasting system in Indonesia since the beginning of its birth is characterized by strong dynamics. First, the broadcasting sector is characterized by strong government regulations that control and dominate until 1989. Indonesian broadcasting system experienced a strong market deregulation in allowing private television operation since 1989, until its development today.

Efforts to build a democratic broadcasting system that pays attention to the public gained its momentum in 1998/1999, coincided with Indonesia's political transformation. The whole pressure and advocacy in broadcasting led to the birth of the Broadcasting Law No.32 /2002 with a variety of new hope coloring them. According 
Kitley (2008), “In political terms we can read the enactment of Broadcasting Law 32/2002 as a victory for parliamentary processes and power over the executive". This Law ensures fairness of various interests by dividing the broadcasting system through four institutions: public TV, community TV, Commercial-private TV and pay-TV. But in reality, the legislation written in the background of transformation is not long-lived. Critics continue to roll, until the demands to change the Law.

From the perspective of public interest, this situation is not so favorable. Broadcasting regulation which optimize the broader public interest, has many obstacles in its implementation. Indonesian broadcasting system has serious weaknesses as frequently employed by various parties placed as political and economic agents. The increasing number of television stations owned by political actors, as well as the gigantic media business development affect the complex economic and political constellation, as well as the lifestyle and culture of Indonesia society.

\section{A. Complexity of 4 Sub-Systems as Pillars of Indonesian Broadcasting System}

\section{The Problem of Public Broadcasting - TVRI System}

TVRI or Republic of Indonesia Television is the first television station in Indonesia. TVRI was established on the initiative of the first President of Indonesia, Ir. Sukarno. The premiere broadcasting of TVRI was in the form of trial broadcast on August 17, 1962, namely a special broadcast coverage of the memorial service of Independence Day of Republic of Indonesia. Then, on August 24, 1962, TVRI officially broadcasted the official opening of ASIAN GAMES IV. When the President issued Presidential Decree No. 215 of 1963, a foundation was then established, namely the Foundation of Republic of Indonesia Television as the manager of this station. Following the incident on September 30, 1965, which resulted in the regime's transition of authority, from Sukarno to Suharto, TVRI was no exception to undergo a significant impact of New Order regime under Soeharto, making TVRI as a Technical Implementation Unit (UPT) of the Ministry of Information. More specifically, TVRI is under the Directorate of Radio, Television and Film, or more widely known as RTF. TVRI became a television of government's 'mouthpiece'. Within 32 years, TVRI had been used as a medium for propaganda by the New Order government (Wahyuni, 1998).

Following the Reformation in 1998, President Abdurrahman Wahid or was familiarly called Gus Dur, decided to dismiss the Ministry of Information serving as the host for TVRI on October 16, 1999. With the dismissal of Ministry of Information, the legal status of TVRI turned into Bureau Company under the Ministry of Finance. It was stipulated by Government Regulation number 36 in 2000. When Government Regulation number 9 of 2002 was issued during the reign of President Megawati, TVRI's status was altered once again into Limited Liability Company (PT). TVRI's status alteration into PT at that time made this institution to run in the logic of profit-oriented (FGD TVRI, 2014).

Once Broadcasting Law No. 322002 was put into effect, TVRI returned to its "ideal form" as a broadcasting agency which was oriented to public interest. In Chapter 14 of this Law, it is mentioned that the Public Broadcasting Institution is comprised of Republic of Indonesia Radio and Republic of Indonesia Television. Subsequently, TVRI as Public Broadcasting Institution was more specifically set out in the Government Regulation (PP) No. 11 of 2005 on LPP and Government Regulation (PP) No. 13 of LPP TVRI.

In 2016, TVRI had one national broadcasting station in Jakarta and 28 regional broadcasting stations. TVRI had 380 transmitters distributed in numerous parts of Indonesia, but out of them, there were only 120 transmitters in 
operation. With such quantity of stations and transmitters, TVRI apparently only had a range power of 34\% (see http://www.dpr.go.id/id/). Local stations of TVRI throughout Indonesia include Western Indonesia, central or middle Indonesia and Eastern Indonesia territory. TVRI appears to have not yet escaped from the issues occurring to it related to its organization's structure and culture. Internally, TVRI is yet capable of developing a reliable system of public strengthening. The organizational culture that remains strong as the government broadcasting organization has complicated the organizational transformation supporting the spirit of public.

As the public broadcasting, TVRI is directly responsible to the President. However, it needs certain ministries as the partners in technical level. By the end of 2016 the mechanism regarding the governance of public broadcasting TVRI and RRI is still unclear. At least 3 ministries always mentioned as the broadcasting partners in the discussion with the member of Commission I of Indonesian House of Representative (DPR-RI), namely the Ministry of Communication and Information, Ministry of Finance, Ministry of Defence. The commission has different reasons why they mentioned certain ministries as the partners of public broadcasting. However, the solutions in the technical level are still unclear. The unclear position in national level brings so many implications in the performance of TVRI. The burden of its history as the government agent makes it very difficult for TVRI to transform their image as a public TV. The burden of its numerous officers with their status as government officers while TVRI as the public broadcasting institutions also influence the quality of organization.

The demand and hope from the society to the existence of TVRI as a public broadcasting institution is still unfulfilled (Intani, 2012). The internal requirements are very weak to realize good public broadcasting governance in
Indonesia. There are some evidences that TVRI is weak as the public broadcasting institution, namely the audience share of TVRI is very low, the program can not compete with other private-commercial broadcasting, and has many burdens in managing their organisations. Some conflict between supervision board of TVRI with parliament, and also unclear mechanism as public broadcasting institution shows that there are still many problems burden TVRI. Under President Jokowi's administration there are some efforts to make TVRI become central again, such as pointing out TVRI as the pilot project coordinator for digitalization process in Indonesia. However, to make TVRI substantially strong, it needs numerous efforts and policies in this context.

\section{The Problem of Private-Commercial TV System}

Since their emersion in 1989, privatecommercial televisions in Indonesia have been receiving huge easiness in running their operation. After being dominated by stateowned television for a long time, private televisions have become a major alternative for television viewers in Indonesia. One of several reasons for the establishment of Indonesian private televisions is to provide alternative shows for Indonesian public in the border area with foreign countries. Initially, private television operated in several regions in Indonesia, for example, AN-TV in Lampung and SCTV in Surabaya, but with the opening of broadcasting possibility from Jakarta, nearly all private televisions were broadcasted from Jakarta. Until 2015, there are approximately 13 private stations - commercial operating in Jakarta and airing with an infinite range from Jakarta to Papua.

The emersion of local commercial private TV stations became a response of disappointment towards the performance of national television that was considered too dominant and controlled ads circulation 
throughout Indonesia. Private commercial broadcasting can advertise with national range from Jakarta to all region in Indonesia. The parties considered that in any given area where ads circulation with tremendous potential exists and will be more primary if utilized by actors of local media.

Looking back at the history of private televisions in local regions, the emergence of local televisions had to cope with the power of private televisions at the national level. At that moment, supporting groups of local private televisions fought for the presence of local private televisions on the rationalization to ensure diversity and promote the style of localities in Indonesia. Local TV stations bring their specific local value in their programs. They founded the Association of Indonesian Local Televisions (ATVLI) that later must deal with Association of Indonesian Private Televisions (ATVSI). They considered that private televisions in local region should also get a portion also to try and optimize the industry at the local level.

Since their emersion until 2016, 75 local televisions have been developed throughout Indonesia (see www.atvli.or.id). In its development, local private televisions are not entirely able to maintain their referred localities. The business practice of which its battle has moved to a more local level is a less encouraging phenomenon. Another thing that later happened is a phenomenon when national televisions also take part and do business cooperation with local actors. Hence what happened is the lack of local programs that ought to dominate local TV stations.

Not only engaged in the world of television at the national level, major media company group in Indonesia increasingly begin to expand to local regions. There are two ways of expansion, either by building new local media or acquiring (join group) of the media existed in the region. The agreement of local media in the region to join major media group is due to several affecting factors, one of them is the financial and managerial resources that are considered promising. Those are the great overview of private commercial television system, both at national and local level in Indonesia. Private television stations are adored but also hated at the same time. These TV stations are very popular for its programs and has high audience share, however in the same time people criticize its program quality as is deemed to be far from having good quality (Rianto, 2012).

In Indonesia, the entire technical matters, such as licensing and procedure for broadcasting implementation, are regulated through Minister Regulation and Decree, in this case is the Minister of Communication and Information. Specifically, private commercial broadcasting is further regulated by Government Regulation (PP) No. 50 of 2005 on Private Broadcasters, and Government Regulation (PP) No. 52 of 2005 on Subscribed Broadcasters. When explored further, there is no systematic controlling system to regulate the practices private televisions organization, thus they can perform their role optimally and are more beneficial to the public interest. In the existing regulations, private broadcasters are given optimal space in profit-oriented television business. On its journey, this logic of the private broadcasting system is what dominates the practice of TV organization in Indonesia, and public interest automatically, doesn't become priority anymore (Rahayu, 2014).

The state, particularly the Government that should become the protector of public interest is having an affair with the capitalists instead. Law 32/2002 which was further derived into a number of regulations, such as Government Regulation and Decree of Minister, now only becomes words without meaning. A number of law derivatives are in contrast to the spirit to realize democratic broadcasting existing on the Law itself. Private broadcasters cannot control the dominance of commercial interest in their shows so 
that the communication with public content is extremely low. Market interest and the dominance of financiers cannot be controlled with the ethical expectations of idealistic media as a social institution.

Commercial private television in Indonesian broadcasting system has a complicated problem. All of the problems were caused by the regulator, that since the beginning of broadcasting industry, came up with no concepts and unclear broadcasting blueprints (Wahyuni, 2006). The existence of broadcasting regulation can not guide the clear mechanism of broadcasting process, the weak of implementation is also another serious problem. The influence of dynamic market in global economy is another factor but not the primary factor. The role of public as part of system is never as the primary concern in Indonesian Broadcasting System. The Government has no sufficient readiness to comprehensively regulate the system of Indonesian national broadcasting, even over 19 years after political reform. A healthy commercial private broadcasting system that ensures the quality of strong public information at least should fulfill some conditions: ensuring certainty business competition environment, clear rules, ensuring healthy relationship between actors in accordance with its role and function, all players in the private commercial broadcasting system should comply with the ethics as a guide in every steps to run the business. In this context, business and ethics should go hand in hand so that both can be optimized in accordance with the expectations of society, and commitment to public interest needs to be kept alive in every step taken and breakthrough business done. Setting the television business is unlike regular business. In order to avoid communities at risk (risk society) it will require courage from each party to discuss the weaknesses of existing broadcasting system to further reinforce the television broadcasting system.

\section{The Problem of Pay-TV and Community TV System}

The role of Pay-TV in supporting public interest isn't significant enough to discuss. It is because Pay-TV stations only provide service for limited public or only for their subscribers. In the following years, the competition in pay TV industry increased and gets tougher. As of December 2014, there were 17 big pay TV operators in operation. Indovision is the main actor in this domain. The competition between pay or subscription TV providers tightened when several other new providers entered the domain. ${ }^{1}$ Number of pay TV subscribers in Indonesia in 2012 is 2.4 millions, and predicted will increase to 7.1 millions in 2017 and 8.7 millions in 2020. ${ }^{2}$ Pay-TV in Indonesia seems to be oriented towards entertainment. It is set to be TV which specifically provides entertainment for those who subscribe.

\section{The Problem of Community TV System}

According to Association of Indonesia Community TV (ATVKI), the number of community TV stations in Indonesia is 31 televisions. Some of community tv stations in Indonesia are Grabag TV in Magelang, Rajawali TV in Bandung, Madani TV in Depok, Al Washilah TV Kebon Jeruk-Jakarta, and some community tv of senior high school and universities. Community televisions emerge based on the mandate of Law No. 32 of 2002 on broadcasting, particularly article 21 clause 2 point 2 which states that LPK is held to educate and reinforce the society in achieving welfare through their programs which include culture, education and information which describe the identity of the nation. Community tv also regulate by Government Regulation (PP) No. 51 of 2005 of LPK. In fact, the development

\footnotetext{
See http://www.thejakartapost.com/news/2015/01/22/ pay-tv-market-too-crowded-operators-say.html.

2 See https://www.statista.com/statistics/257298/pay-tvsubscribers-in-indonesia/.
} 
of community television in Indonesia, faced some internal and external problems. Internal problem related with the quality of human resources and management issue in community broadcasting. While external problem related with the regulation issue in macro level. Regulations do not accommodate this type of broadcasting institution (community TV). The prepared system is not reliable enough to embody community TV as a media that strengthens public. Community media (TV) has to face serious technical problems, funding issue, and community involvement in the management.

\section{B. Indonesian Broadcasting Policy from the System Perspective}

From the system perspective, especially using Buckley's perspective (Johnson, 2008), Indonesia broadcasting system tends to have minimum morphostatic process. This fact related with the limited feedback to the existence problem within the system. Instead, it tends to have morphogenesis process (amplifying deviation feedback) and create entropy condition. Generally, the system develops to respond the system with numerous deviations, yet doesn't produce any breakthrough. The system cannot adaptively give feedback to its very dynamic environment. The system shows signs of entropy or shrinkage condition. The external environment is more developed and can't be matched by the internal system. Feedback cycle can't guarantee the system to develop in achieving its purpose optimally or negentropy condition. Conversely, it is static and moves further from the ideal system.

From the autopoetic system, especially in communication element, Indonesian broadcasting system failed to communicate with external environment. Relationship between the sub element of broadcasting system with the environment (stakeholders) has not been managed. In this communicating system, broadcasting system has been dominated by interpretations of political system or economic system which probably has seen broadcasting system as a very strategic media for its interests. The political system which tends to be dominant in the atmosphere of the social system in Indonesia has made broadcasting a significant subsystem to reach specific objectives of the political system. At the same time, the development of television industry makes broadcasting system a very productive economic subsystem in encouraging capital movements. The competing system makes television a specific arena which blurs its position as social and cultural systems. From the beginning, public, social and cultural systems have a small role so that the input from both public social and cultural systems which ought to be the basis of broadcasting system development is not well accommodated. Indonesian broadcasting system communicates with political system and economic system more intensely and displays it in their programs, but its role and power in social and cultural aspects are almost invisible.

Based on temporal element, the growth of Indonesian broadcasting system in the past 19 years post-political reformation 1998 showed evolutionary achievements. There are some important moments which mark this phase. 2002 marked the birth of Law of Broadcasting No 32/2002. This law is the basis of Indonesian broadcasting system organization which becomes the compass of Indonesian broadcasting system organization post-political transition in 1998. After a lengthy argument since 1999 until it has passed in 2002, the Law of Broadcasting shows various interests in its practice. At least three main actors, from the government to business groups to civil society joined dynamic debates, and many intermediary actors who had equal roles in influencing the end result of Indonesian broadcasting system. Political caucuses were formed based on the character of legislative political dynamic of DPR at that time. Unfortunately, politically 
strong dynamics didn't produce optimal compromise or consensus.

Soon, in 2004 this Law was judicially reviewed by a private group, and then various other groups, so that Indonesian Broadcasting Commission also performed a judicial review on the Law of Broadcasting. Crucial articles which changed after the judicial review were articles which reduce the authority of Indonesian Broadcasting Commission and enable the government to determine and make policies on frequency and various policies in broadcasting with Indonesian Broadcasting Commission.

As an evolution, political transformation 1998 encouraged a new direction in broadcasting system but then had revision in the structure, relation, and authority in the pool of economic and political interests. Unfortunately, in terms of evolution, it is clear how the public missed many things. Stories on ownership of private television stations and how to monitor their performance are difficult to trace. Concerns are only raised in limited discussions in the society which aren't represented in the macro structure of policy makers. The performance of Indonesian broadcasting system allows commercial private groups to operate, as shown in various information and entertainment productions from the private domain. Mainstream media is the most reliable reality construction agent and is a strong influence in forming opinions in the society. Freedom to do business in the media also causes privatization logics in information management unavoidable.

Concentrations of ownership, whether vertical or horizontal, cannot be avoided. The ownership of around 10 televisions which air nationally through terrestrial network is narrowed to a certain group which unfortunately grows stronger and inseparable from political interests (Nugroho, 2012). Information is commodity and rationality construction is handed to market and political logics. Interestingly, the evolution of Indonesian broadcasting system affects market failure in presenting quality information which is expected in the life of democratic society.

The imbalance between pro-market structure and weak public system in Indonesian broadcasting system results in the quality of information which represents this kind of structure atmosphere. Public sphere in Indonesia strongly coloured by market and politic interest. Finally, public trust on the performance of Indonesian television broadcasting which is very politically and economically biased declines sharply. From this perspective, temporal evolution seriously regresses in terms of democracy and further, can not fulfill public's expectation for the creation of ideal broadcasting system for Indonesia.

Since 2012 Indonesian broadcasting system also prepares themselves to meet the planned digital broadcasting systems which will be implemented in 2017/2018. In this context, the development of technology that is an unstoppable force toward the development of Indonesian broadcasting is in logic technology. The regulations from the beginning are dominated by the economic and political logic back to be tested along with the inevitable logic technology. Portrait of digital broadcasting system evolution in Indonesia until 2016 has not been able to reach the stages which had been planned to achieve optimal point in 2017/2018. This plan has re-tested because of the protests from various circles that are concerned about the implementation of digital systems in the broadcasting system in Indonesia.

From the differentiation element, the main question, how will Indonesian broadcasting system differentiate functions to address existing problems? Can Indonesian broadcasting system be said to be dynamic or static in answering the complexity of environmental problems? Looking at the facts before, it can be said that the ability of Indonesian broadcasting system in performing 
functional differentiation to address the complexity of existing problems is very weak. The functions in the system have not been able to reflect the optimal differentiation which should be reflected in the internal system. In Indonesian broadcasting system, several crucial functions that should present to answer the challenges of the broadcasting environment and the achievement of national goals can finally be formulated into differentiation main functions as follows:

1. The function of national broadcasting system strengthening a multicultural perspective of Indonesia.

2. The function of regulatory and monitoring mechanisms strengthening for democratic broadcasting system.

3. The function of the digital broadcasting system to gain optimized principle of public protection in accordance with the character of Indonesian society namely agrarian, industrial, post-industrial, and informative.

Weakness in the three elements of cybernetics as described above carries a portrait of autopoetic-mechanism very weak. Indonesian broadcasting system is still not able to develop a communication system that maps the problem optimally.

Ultimately the perspective from Luhmann autopoetic indeed signaled an evolution without end, he offered how to keep the system continue to grow and find a way dynamic system that optimally answers the real challenges faced. In this logic there is hope that Indonesian broadcasting system continues to sharpen the ability to capture the problem, build evolution differentiation and develop a system that ensures goal achievement system. There is no perfect recipe for solving broadcasting Indonesia problems, what can be done is to continue to evolve in developing functional differentiation in Indonesian broadcasting system. The new direction of the broadcasting system development is more equitable and oriented toward the interests of the wider public needs to be continually sought and optimized. Broadcasting system with the new direction is broadcasting systems that adaptively solve the problems that had been raised and addressed in a variety of public discussion.

Structuring and re-regulating Indonesian television broadcasting industry approximately 28 years since its birth in the period 1989, leaves a lot of homeworks. The issue of how television could produce cultural products with high quality, the issue of how to reduce the strong desire of politicians to maintain control over media operations, efforts to reduce violations and negative implications of media, building a reduction system concentration, diversity, national culture, and integrity of minorities, fairness distribution of new communication channels, and the strength of an increasingly globalized media ownership. Solutions are seriously needed to solve all of these issues so that the presence of private television commercial in Indonesia can mobilize the community better and if possible, to transform the lives of the Indonesians for a higher quality of life.

\section{Conclusion}

Expectations for the realization of democratic broadcasting system that puts the public interest in priorities by the presence of broadcasting Law number 32/2002 still can not happen. The fact that seems exactly alarming, when the market becomes the new ruler of Indonesian broadcasting world, is assisted by the Government. Competition is very fierce and dominated by commercial private groups at the same time have been able to dominate the sphere of public discourse in Indonesia. On the other hand, public areas are managed by the public media are less able to dominate the discourse because of various limitations facing the public media (Public Broadcasting television and Community TV).

The effort to develop robust broadcasting system that reinforces public absolutely 
necessary. The communication policy makers need to continue to develop a discourse about the importance of strengthening public broadcasting system. Currently, Indonesian government is developing the new broadcasting regulations especially Public Media Act which is being awaited. The portray shows the weakness of public broadcasting institutions in Indonesia really needs a breakthrough alternative to existing broadcasting system that offers a dynamic and novelty in broadcasting world of Indonesia. Public needs to be ignited by the implementation of stronger public sectors. Public sector currently exists institutionally but has not been properly implemented. Concerns on public system in Indonesia unfortunately only come from certain limited circles, so for the foreseeable future has to continue to look for an alternative system to the development of better Indonesian broadcasting system.

Policy makers for television broadcasting Indonesia are expected to perform the steps and breakthroughs to a variety of problems that are very complicated and increasingly sophisticated in the regulation of Indonesian broadcasting system. With the condition in which every element has specific problems, to reduce the complications, regulator should take a look in each sub system. They need to place all sub systems in the corridor of the initial objectives in the general level.

The government's role as coordinator of policy decisions need to be taken seriously to be capable of providing a discussion platform between numerous different parties. Each system has different goal so they can be united for a greater purpose. The government's attitude wich tends to allow each actor to translate and execute their willingness sector for their own aims should be stopped. The Government should have clear directions to regulate all interests because it will have a bad impact that brings Indonesians in conditions of risk communication. Broadcasting policy makers, should immediately consider to protect the public through the stronger national broadcasting system which bring the benefit of the broader Indonesian community. The public discussion to strengthen the governance of broadcasting system should be continued to create broadcasting system which is more adaptive with real problem that they should face.

\section{References}

Broadcasting Regulation No 32/2002.

Creech, K. C. (2007). Electronic Media Law and Regulation. USA: Focal Press.

Curran, J. (2002). Media and Power. London: Routledge.

Farhat, S. (2013). TVRI butuh 130 Milyar untuk Maksimalkan Jangkauan Siaran. Retrieved from http://www.dpr.go.id/id/ berita/komisi1/2013/jul/02/6264/tvri-butuh130-milyar-untuk-maksimalkan-jangkuansiaran-.

Fleck, F.H. (1983). Klassische, Magische Vielecke in Wirtschaftspolitik - und in Medienpolitik? In: Rühl, Manfred and Stuiber, HansWerner (eds.), Kommunikationspolitik in Forschung und Anwendung. Festschrift für Franz Ronneberger (pp. 77-86). Düsseldorf: Droste.

Flick. U. (2005). An Introduction to Qualitative Research. London: Sage Publications.

Government Regulation (PP) No. 11 of 2005 on LPP.

Government Regulation (PP) No. 13 of LPP TVRI.

Government Regulation (PP) No. 50 of 2005 on LPS.

Government Regulation (PP) No. 51 of 2005 on LPK.

Government Regulation (PP) No. 52 of 2005 on LPB.

Griffin, E.M.(2012). A First Lookat Communication Theories. Eight Edition. USA: Mc Graw Hill Company.

Hendriyani, Hollander, E., d'Haenens, L., \& Beentjes, J. (2011). Children's Television 
in Indonesia. Journal of Children and Media, 5(1), 86-101.

Hollander, E., d'Haenens, L., \& Bardoel, J. (2009). Television Performance in Indonesia: Steering between Civil Society, State and Market. Asian Journal of Communication, 19 (1), 39-58.

Intani, R. (2012). Reinvensi dan Implementasi Atas Pemaknaan Televisi Publik (Studi Kasus Mengenai TVRI sebagai Lembaga Penyiaran Publik). Dissertation under Universitas Padjajaran Bandung, Un-published.

Johnson, D.P. (2008). Contemporary Sociological Theory: An Integrated Multi-Level Approach. New York: Springer Science+Business Media, LLC.

Kellner, D. (1990). Television and the crisis of Democracy. Boulder: Westview Press.

Kitley, P. (2003). Television, Regulation and Civil Society in Asia. London: Routledge.

Kitley, P. (2008). In court with the Indonesian Broadcasting Commission: Old Battles And New Identities in the Context of Reform. The Pacific Review, 21(3), 351-367.

Kominfo. (2015). Buku Saku Hasil Survey Indikator TIK 2015 Rumah Tangga dan Individu. Jakarta: Pusat Penelitian dan Pengembangan Penyelenggaraan Pos \& Informatika, Badan Penelitian dan Pengembangan Sumber Daya Manusia, Kementrian Komunikasi \& Informatika.

Lee, D. (2000). The Society of Society: The Grand Finale of Niklas Luhmann. Sociological Theory, 18(2), 320-330.

Luhmann, N. (1992). What is Communication? Communication Theory, 2(3), 251-259.

Luhmann, N. (1995). Social System. Stanford: Stanford University Press.

Mattheis, C. (2012). The System Theory of Niklas Luhmann and the Constitutionalization of the World Society. In Goettingen Journal of International Law, 4(2), 625-647.

May, R. J. (2009). New Directions in Communication Policy. USA: Carolina Academic Press.
Mc Quail, D. (2010). Mass Communication Theory. $6^{\text {th }}$ Edition, London: SAGE Publications.

Mosco, V. (2010). The Political Economy of Communication. $2^{\text {nd }}$ Edition. Great Britain: Sage Publications.

Nugroho, Y., Putri, D.A. \& Laksmi S. (2012). Mapping the landscape of the Media Industry in Contemporary Indonesia. Report series. Ford Foundation, Jakarta: CIPG and HIVOS.

Papathanassopoulos, S., \& Ralp, N. (2010). Communications Policy, Theories and Issues, UK: Palgrave Macmillan.

Rahayu. (2014). Kinerja Reguator Penyiaran Indonesia. Yogyakarta: PR2Media \& Tifa.

Rianto, Puji. (2012). Dominasi TV Swasta Nasional: Tergerusnya Keberagaman Isi dan Kepemilikan. Yogyakarta: PR2Media-Yayasan Tifa.

Ritzer, G. \& Goodman, D.J. (2004) Teori Sosiologi Modern. $6^{\text {th }}$ Edition. Translation Alimandan. Jakarta: Prenada Media.

Sudibyo, A. \& Patria, N. (2013). The Television Industry in Post-authoritarian Indonesia. Journal of Contemporary Asia, 43(2), 257-275.

Sudibyo, A. (2004). Ekonomi Politik Media Penyiaran. Jakarta: ISAI.

Tassel, J.V., \& Howfield L.P. (2010). Managing Electronic Media, Making, Marketing, and Moving Digital Content. USA: Elsevier.

Thussu, D.K. (2007). News as Entertainment: The Rise of Global Entertainment. London: Sage Publications.

Vowe, G. (1999). Medienpolitik zwischen Freiheit, Gleichheit und Sicherheit. In Holtz-Bacha, Christina, Kutsch, Arnulf, Langenbucher, Wolfgang R; Saxer, Ulrich (Eds.) Publizistik. Vierteljahreshefte für Kommunikationsforschung, 403-405. Wiesbaden: Westdeutscher Verlag.

Wahyuni, H.I. (1998). Televisi dan Intervensi Negara. Yogyakarta: Media Pressindo.

Wahyuni, H.I. (2006). Broadcasting Regulation. Yogyakarta: FISIPOL UGM.

Wahyuni, H. I. (2006). The Struggle to Create a Democratic Broadcasting System after 
Hermin Indah Wahyuni, Complexity and Adaptive System of Television Broadcasting: The Reflection of Autopoetic Mechanism of Indonesian Television Broadcasting System

Political Transformation 1998. Dissertation under Leipzig University, Germany. Unpublished.

West, R. \& Turner, L.H. (2010). Introducing Communication Theory: Analysis and Application. Boston: McGraw-Hill.
Wimmer, R.D. \& Dominick, J.R. (2011). Research Methods, Mass Media Research An Introduction. (Ninth Edition). Boston: Cengage. www.atvli.or.id. 